\title{
Use of Poultry Droppings and Wood Ash as Soil Amendment and its Effect on Soil Properties and Yield of Maize
}

\author{
C.N. Mbah ${ }^{1}$, O. A. Dada ${ }^{2}$, T. N. Okoro ${ }^{1}$ and A. Ifejimalu ${ }^{2}$ \\ ${ }^{1}$ Department of Soil and Environmental Management, Ebonyi State University, Abakaliki, Nigeria \\ ${ }^{2}$ Department of Agriculture, Alex Ekwueme Federal University, Ndufu-Alike, Ikwo, Ebonyi State
}

Nigeria

\begin{abstract}
Improvement in soil physicochemical and biological properties through the use of organic amendment is necessary for increased crop yield. This study evaluated the effects of poultry dropping, (PD) and wood ash (WA) on soil properties and maize grain yield in an ultisol in southeastern, Nigeria. The experiment was a randomized complete block design with four treatments replicated

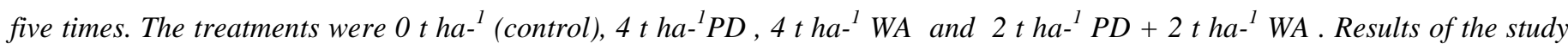
showed significant $(p \leq 0.05)$ decrease in bulk density and increase in total porosity in amended soil relative to the T1 (control). Similarly, soil chemical properties $(\mathrm{Ca}, \mathrm{Mg}, \mathrm{pH}, \mathrm{OM}$, avail $\mathrm{P}, \mathrm{Na}, \mathrm{K})$ were significantly increased relative to the control. Application of the amendments increased maize grain yield relative to the control with highest increased observed in $4 t$ ha- ${ }^{1} P D$ amended plots. The use of PD and WA for soil property improvement and increased crop yield is recommended for the studied soil.
\end{abstract}

Keywords: Poultry droppings, Wood Ash, Soil Properties, Maize Yield.

\section{INTRODUCTION}

Soil is a fundamental resource for agricultural production since it serves as reservoir for plant nutrient (Brady, 1999). Soil affects human health directly through the injection, inhalation and absorption of soil or its constituents and indirectly through the quality and quantity of food that is derived from the soil based agriculture (Oliver and Gregory, 2015). Some of these effects can be detrimental to health, if toxic substance or pathogenic organisms enter the food chain and are passed to human (Brevik and Burqess (2013).

Soils of south east, Nigeria are acidic hindering proper agricultural production, since most of the crops grown are susceptible to the dangerous effect of acidic soils. Ohiri and Ano (1989) reported that the acidic nature of the soil in south east, Nigeria was due to their parent material, leaching and degradation in the soil physical properties. Igbokwe et al. (1981) reported the use of wood ash to reduce or make the soil less acidic. Soils of southeast Nigeria are observed to be low in organic matter content (Enwenzor et al,. 1988). Study by Mbah and Mbagwu (2006) showed that the low organic matter content of these soils can be arrested by the use of organic wastes. Poultry manure (dropping) is organic manure found in peri-urban areas of southeastern Nigeria. Ojeniyi (2007) reported that poultry manure effectively increased soil fertility, crop yield and nutrient content of soils.

Maize (Zea mays L.) belongs to the grain under the family graminae and class of cereals that thrive under a wide range of environmental conditions. Maize does well with pH $5.5-5.7$ while strongly acidic soil pH $(\leq 5.0)$ is unsuitable for good yield. Poultry manure and wood ash are easily sourced in the study area but researches on their use as soil amendment is at infant stage in the study area. 
This study was aimed at determining the effect of poultry dropping and wood ash and their combination on soil properties and yield of maize (Zea Mays L.) in a degraded ultisol in Abakaliki, Southeast Nigeria.

\section{MATERIAL AND METHODS}

The experiment was conducted at the Teaching and Research Farm of Faculty of Agriculture and Natural Resources Management of Ebonyi State University, Abakaliki which is located on longitude $5^{\circ} 36^{1}-6^{\circ} 45^{1}$ and latitude $7^{\circ} 45^{1} \mathrm{E}-8^{\circ} 30^{1} \mathrm{E}$ in the derived savannah zone of Nigeria. The area is characterized by high rainfall between $1800 \mathrm{~mm}-2000 \mathrm{~mm} .21^{\circ} \mathrm{C}-29^{\circ} \mathrm{C}$, respectively. The rainfall regime is bimodal with the peak in July and September. The soil is hydromorphic and belongs to the order ultisol within Ezzamgbo soil association, derived from shale and classified as Typic Haplustult (FDALR,1985). The soil have been reported to be acidic, low in organic matter content, cation exchange capacity and other essential nutrients (Enwezor et al. 1988, Nnabude and Mbagwu, 1998).

Some of the properties of the study soil is shown in Table I. At the beginning of the experiment in 2017, the land was cleared of predominant grass (Imperata cylindrical) and tillage operation was done using traditional hoe. Poultry dropping was sourced from Nkaliki poultry farm while wood ash was obtained from Abakaliki market. The treatment consisting $4 \mathrm{t} \mathrm{ha-}^{1}$ poultry dropping (PD), $4 \mathrm{t} \mathrm{ha-}^{1}$ wood ash (WD), $2 \mathrm{t} \mathrm{ha}^{1} \mathrm{PD}+2 \mathrm{t} \mathrm{ha-}{ }^{1} \mathrm{WD}$ and $0 \mathrm{t}$ ha-1 (control) were spread evenly on appropriate plots (measuring $3 \mathrm{~m}$ by $4 \mathrm{~m}$ ) and incorporated into the soil during tillage. The experiment was arranged in a randomized complete block design (RCBD) with four treatments and five replications.

A total of 20 plots each measuring $3 \mathrm{~m} \mathrm{x} 4 \mathrm{~m}$ were used for the study. Plots were separated by a buffer of $0.5 \mathrm{~m}$ and each replicate was $1 \mathrm{~m}$ apart. Two maize seed (Oba super II) were planted per hole following treatment application. Planting was done with a spacing of $50 \mathrm{~cm}$ with row and $50 \mathrm{~cm}$ between rows with planting depth of $3 \mathrm{~cm}$. The seedling were thinned down to one plant/stand two weeks after germination (WAG). Lost stands were replaced and weeding done manually at three weeks intervals.

At the beginning of the experiment composite soil samples were collected from six points at $0-20 \mathrm{~cm}$ depth. Similarly, at the end of the experiment soil samples were collected from each plot at $0-20 \mathrm{~cm}$ depth. These samples were air-dried at ambient temperature, sieved through, sieved through a $2 \mathrm{~mm}$ sieve and used for routine analysis. Core soil samples were collected from 4 observational points at 90 days after planting (DAP) and used to determine soil physical properties.

The following analysis were carried out in the Laboratory. Bulk density was determined using core method (Grossman and Remca, 2002). Total porosity (TP) was calculated from bulk density value using the formula $\mathrm{TP}=100(1-\mathrm{Bd} / \mathrm{pd}) \mathrm{where} \mathrm{Bd}=\mathrm{bulk}$ density, pd = particle density assumed to be $2.65 \mathrm{gcm}^{-}{ }^{3}$. Percentage water content was determined by the method described by Klute (1986). Soil pH was measured potentiometrically on a 1:25 soil/water solution (Henderson et al., 1993). Cation exchange capacity was estimated by ammonium acetate at pH 7 (Soil Survey Staff, 2003) while exchangeable bases (Ca, Mg, Na, K) were extracted with ammonium acetate by PerkinTimer atomic absorption spectrophotometer (Tel and Rav, 1982). Exchangeable acidity was obtained according to Ruo (1979) method. The percentage organic matter (\%OM) was calculated by multiplying the value of OC by the conventional "Vanbemeller factor" of 1.724 on the assumption that soil organic matter (SOM) contains $58 \% \mathrm{C}$ (Allison, 1982). At 14 weeks after planting 18 plants representing $40 \%$ of the plant populations per plot of $3 \times \mathrm{m}^{2}$ were sampled for height and grain yield measurement. They were sun dried and the shelled grain was measured at $17 \%$ moisture content.

Data from the study were subjected to analysis of variance test based on RCBD according to Steel and Torre (1980)

\section{EXPERIMENTAL RESULT}

Table 1: selected properties of the soil before the study

\begin{tabular}{|c|c|c|}
\hline Soil Property & Unit & Value \\
\hline Sand & g/kg & 721 \\
\hline Silt & \multicolumn{1}{|c|}{} & 186 \\
\hline Clay & \multicolumn{2}{|c|}{ Sandy loam } \\
\hline Texture & - & 93 \\
\hline pH & $\mathrm{mg} / \mathrm{kg}$ & 5.30 \\
\hline P & $\mathrm{g} / \mathrm{kg}$ & 3.06 \\
\hline Total N & $\%$ & 0.08 \\
\hline Organic matter & $\mathrm{Cmolkg}^{-1}$ & 1.67 \\
\hline Ca & " & 0.80 \\
\hline Mg & & 0.08 \\
\hline
\end{tabular}


C. N. Mbah et. al., Use of Poultry Droppings and Wood Ash as Soil Amendment ....

\begin{tabular}{|c|c|c|}
\hline Na & “ & 0.08 \\
\hline $\mathbf{K}$ & “ & 0.07 \\
\hline
\end{tabular}

Table 2: Nutrient composition of the amendments

\begin{tabular}{|c|c|c|c|}
\hline Parameter & Unit & Wood-ash (WA) & Poultry Droppings (PD) \\
\hline $\mathbf{C a}$ & Cmolkg $^{-1}$ & 21.22 & 4.70 \\
\hline $\mathbf{M g}$ & " & 10.28 & 2.14 \\
\hline $\mathbf{N a}$ & “ & 1.65 & 1.00 \\
\hline $\mathbf{K}$ & " & 3.50 & 2.14 \\
\hline $\mathbf{N}$ & $\mathrm{g} / \mathrm{kg}^{-1}$ & 4.80 & 2.2 \\
\hline $\mathbf{P}$ & $\mathrm{Mgkg}^{-1}$ & 1.80 & 2.70 \\
\hline $\mathbf{O M}$ & $\%$ & 1.80 & 16.5 \\
\hline
\end{tabular}

The texture of the soil was sandy loam. The soil has the $\mathrm{pH}$ value of 5.3 and total $\mathrm{N}$ value of 3.06. The exchangeable bases Ca, $\mathrm{Mg}, \mathrm{Na}$ and $\mathrm{K}$ values of the soil were $0.80,0-08,0.08$ and $0.07 \mathrm{cmolkg}^{-1}$ respectively (table 1). Analysis of WA and PD (Table 2) showed $\mathrm{Ca}, \mathrm{Mg}, \mathrm{Na}$, and $\mathrm{K}$ values of 21.22, 10.28, 1.65 and 3.50 for WA and $\mathrm{Ca}$ (4.70), $\mathrm{Mg}$ (2.14), $\mathrm{Na}(1.08)$ and $\mathrm{K}(2.24)$ for PD. Higher value of total $\mathrm{N}$ was found in WA compared to PD. Also WA had higher value of $\mathrm{P}$ than PD. Table 2 showed higher values of $\mathrm{Ca}, \mathrm{Mg}, \mathrm{K}, \mathrm{N}$ and $\mathrm{P}$ in WA and PD compared to table 1. Table 2 also showed that, OM\% was higher in PD than WA.

Effect of wood ash and poultry dropping on soil physical properties

Table 3: Effect of WA and PD on soil properties

\begin{tabular}{|c|c|c|c|}
\hline Treatment & Bd & TP & GMC \\
\hline $\mathbf{0}$ & 1.52 & 43 & 0.17 \\
\hline 4tha ${ }^{-1}$ WA & 1.43 & 46 & 0.18 \\
\hline 4tha ${ }^{-1}$ PD & 1.37 & 48 & 0.19 \\
\hline 2 tha $^{-1} P D+2$ tha $^{-1} W A$ & 1.32 & 50 & 0.18 \\
\hline FLSD $(\mathbf{0 . 0 5})$ & 1.03 & 0.16 & NS \\
\hline
\end{tabular}

3.1 Effect of WA and PD on soil chemical properties

Table 4: Effect of WA and PD on soil chemical properties

\begin{tabular}{lllllllll}
\hline Treatment & $\mathbf{p H}\left(\mathbf{H}_{\mathbf{2}} \mathbf{O}\right)$ & Avail P & \% OM g/kg & \% TN & $\mathbf{C a}$ & $\mathbf{M g}$ & $\mathbf{N a}$ & $\mathbf{K}$ \\
\hline $\mathbf{0}$ & 4.80 & 10.00 & 0.90 & 0.03 & 0.40 & 0.60 & 0.01 & 0.01 \\
4tha $^{-\mathbf{1}} \mathbf{W A}$ & 5.00 & 16.80 & 1.23 & 0.05 & 3.20 & 0.80 & 0.17 & 0.08 \\
4tha $^{-\mathbf{1}} \mathbf{P D}$ & 5.70 & 12.00 & 1.60 & 0.09 & 3.00 & 1.20 & 0.07 & 0.04 \\
2tha $^{-\mathbf{1}} \mathbf{\text { PD+ }}$ & 5.10 & 15.70 & 1.62 & 0.06 & 2.80 & 2.00 & 0.10 & 0.04 \\
2tha $^{-\mathbf{1}} \mathbf{W A}$ & & & & & & & & \\
\hline FLSD (0.05) & 0.03 & & 0.68 & 0.02 & 0.26 & 0.20 & 0.02 & 0.03 \\
\hline
\end{tabular}

Table 5: Effect of WA and PD on plant height and maize grain yield

\begin{tabular}{|c|c|c|}
\hline Treatment & Plant height (cm) & Grain Yield \\
\hline $\mathbf{0}$ & 86 & 1.80 \\
\hline 4tha ${ }^{-1} W A$ & 120 & 2.10 \\
\hline 4tha ${ }^{-1} P D$ & 136 & 2.60 \\
\hline 2 tha $^{-1} \mathrm{PD}+2$ tha $^{-1} \mathrm{WA}$ & 110 & 1.88 \\
\hline LSD (0.05) & 0.71 & 0.09 \\
\hline
\end{tabular}

Result of the study on table 3 show that application of the amendments significantly $(\mathrm{p} \leq 0.05)$ reduced bulk density. Lowest bulk density of $1.32 \mathrm{gcm}^{-1}$ was observed in $2 \mathrm{tha}^{-1} \mathrm{WA}+2 \mathrm{tha}^{-1} \mathrm{PD}$ amended plots. The order of reduction was $2 \mathrm{tha}^{-1} \mathrm{WA}+2 \mathrm{tha}^{-1}$ 
$\mathrm{PD}<4 \mathrm{tha}^{-1} \mathrm{PD}<4 \mathrm{t} \mathrm{ha}^{-1} \mathrm{WA}<$ control. Application of the amendments increased soil total porosity. Highest total porosity of $50 \%$ was observed in $2 \mathrm{t} \mathrm{ha}^{-1}+2 \mathrm{t} \mathrm{ha}^{-1} \mathrm{PD}$. The observed increased was $16 \%, 4.7 \%$ and $9.3 \%$ higher than control, $4 \mathrm{t}$ ha- ${ }^{1} \mathrm{PD}$ and 4 $\mathrm{t}$ ha- ${ }^{1}$ WA amended plots. The result of the study in table 4 showed significant $(\mathrm{p} \leq 0.05)$ increase in the exchangeable bases $(\mathrm{Ca}$, $\mathrm{Mg}, \mathrm{Na}, \mathrm{K})$. The result showed that application of $4 \mathrm{t}^{-}{ }^{-1} \mathrm{WA}$ had highest increase in Ca content. The observed value of Ca was $7 \%$ and $14 \%$ higher than that of control, $4 \mathrm{tha}^{-1} \mathrm{PD}$ and $2 \mathrm{t} \mathrm{ha}^{-1} \mathrm{WA}+2 \mathrm{tha}^{-1} \mathrm{PD}$, respectively. The order o increase in $\mathrm{Mg}$ was 2 tha $^{-1} \mathrm{PD}+2 \mathrm{tha}^{-1} \mathrm{WA}>4 \mathrm{tha}^{-1} \mathrm{PD}>4 \mathrm{tha}^{-1} \mathrm{WA}>$ control. Similarly, addition of amendments increased Na and K content relative to the control with the highest increase in $\mathrm{K}$ and $\mathrm{Na}$ observed in $4 \mathrm{tha}^{-1} \mathrm{WA}$ amended plot. $\mathrm{pH}$ was significantly increased ( $\left.\mathrm{p} \leq 0.05\right)$ in all the amended plots with highest increase observed in $4 \mathrm{t}^{\text {ha- }}{ }^{1} \mathrm{WA}$ amended plots. The order of $\mathrm{pH}$ increase was $4 \mathrm{t}$ ha ${ }^{-1} \mathrm{WA}>4 \mathrm{t}$ $\mathrm{ha}^{-1} \mathrm{PD}>2 \mathrm{tha}^{-1} \mathrm{WA}+2 \mathrm{tha}{ }^{-1} \mathrm{PD}>$ control. Table 4 also showed significant increase in available $\mathrm{P}$ with highest value in $4 \mathrm{t}$ ha${ }^{1} \mathrm{WA}$ amended plots.

Results of the study in table 5 showed that the amendment increased plant height and maize grain yield relative to the control. Plots amended with $4 \mathrm{t} \mathrm{ha}^{-1} \mathrm{PD}$ gave highest plant height with $13 \%, 27 \%$ and $58 \%$ increase relative to $4 \mathrm{t} \mathrm{ha}^{-1} \mathrm{WA}, 2 \mathrm{t}$ ha ${ }^{-1} \mathrm{PD}+2 \mathrm{t}$ $\mathrm{ha}^{-1} \mathrm{WA}$ and control respectively. Similarly, $4 \mathrm{tha}^{-1} \mathrm{PD}$ gave the highest plant grain yield, the order of increase of grain yield was 4 $\mathrm{t}$ ha ${ }^{-1} \mathrm{PD}>4 \mathrm{tha}^{-1} \mathrm{WA}>2 \mathrm{tha}{ }^{-1} \mathrm{WA}+2 \mathrm{tha}^{-1} \mathrm{PD}>$ control.

\section{DISCUSSION}

Texture of the studied soil is sandy loam with particle size distribution of clay (96 $\left.\mathrm{gkg}^{-1}\right) \mathrm{silt}\left(183 \mathrm{gkg}^{-1)}\right.$ and sand $\left(721 \mathrm{gkg}_{-}{ }^{1}\right)$. Anikwe and Nwobodo (2002) observed that sandy loam soils are highly permeable and allows large quantities of leachate to pass through it. Enwezor et al.(1988) showed that this highly permeability has made this soils to be low in plant nutrients.

Results from the study show that the use of PD and WA and mixture of PD + WA as soil amendment improved soil properties through increase in soil $\mathrm{pH}$, increased soil porosity and increase in the soil chemical properties of \%OM, exchangeable bases and increased yield. The observed improvements could be attributed to higher nutrient levels in the amendments (Table 2). Mbah and Mbagwu (2003) reported that PD easily releasing its nutrient to the soil. Similarily, Nottidge et al. (2005) showed that wood ash decompose easily, increase microbial activity and released nutrient in the soil.

Observed higher maize height and grain yield in $4 \mathrm{t} \mathrm{ha-}^{-1} \mathrm{PD}$ amended plots could be attributed to high OM content (Table 2). Mbah et al. (2004) observed that OM supplies plant essential nutrients and improve soil property. Mbagwu (1992) reported that decreased BD observed in rice shaving and poultry manure amended soil were directly related to increased organic matter which played a significant role in reducing soil compaction. The significant decrease in soil BD could be attributed to the direct and indirect effects of soil organic matter (SOM) levels. Directly OM due to its low BD and ability to increase soil aggregate stability result in lower soil BD. Indirectly, the decrease is as a result of bulk density decreased and improved structure as a partly substantiated by porosity increase.

Ojeniyi and Adejobe (2002) reported that ash derived from wood increase N, P, K, Ca and Mg status in soils. Nottidge et al.(2005) reported that ash is involved in direct release of nutrient and increase soil pH. Low BD and high total porosity may have increased root proliferation and hence aid growth of maize. The result of this study agreed with that of Nnabude and Mbagwu (1998) who reported that reduction in soil BD may increase water transmisivity, root penetration and hence cumulative feeding area of the crop which will translate to better yield.

Similarly, Mbah and Itoro (2012) reported increased soil properties and grain yield of maize when the used different rates of PD and WA as soil amendment. Result of the study has shown that organic wastes improved soil properties and increased maize grain yield in studied soil. Their use is therefore recommended for soil acidity increase and amelioration of low nutrient status of the studied soil.

\section{CONCLUSION}

Results of the study showed that the use of poultry dropping (PA) and wood-ash (WA) as soil amendment improved soil properties and increased maize grain yield. It also showed that application of PD at 4t/ha gave the highest maize grain yield. The use of PD and WA as soil amendment in the study area was recommended for soil property improvement and increase in crop yield.

\section{REFERENCE}

1. Allison, F.E (1982). Soil organic matter and its role in crop production. Elsevier scientific publishing company, Amsterdam pp637 
C. N. Mbah et. al., Use of Poultry Droppings and Wood Ash as Soil Amendment ....

2. Anikwe, M.A.N and Nwobodo, K. (2002) Long term effect of municipal waste disposal on soil properties and productivity of soils used for urban agriculture in Abakaliki, Nigeria. Biores.Technol. 98(3) 241 -250

3. Brady N.C (1999). The nature and properties of soils.12 ${ }^{\text {th }}$ Edn. Prentice hall Inc. New Jersey, USA.

4. Brevik, E.C and Burgass, L. C.(eds)(2013) Soil and human health.CRC press. Boca Raton KL

5. Enwerzor, W.O, Ohiri, A.C, Opubaribo, B.E and Udoh, E.J (1988). A review of fertilizer use of crops in south eastern zone of Nigeria.Fertilzer procurement and distribution department, Lagos

6. FDALR, (1985), Reconnaissance soil survey of Anambra state, Nigeria. Soil report FDAIR, Kaduna

7. Grossman, R.B and Reinca, T. G (2002). Bulk density and linear expansibility in J.H. Dane and G.C. Topp(eds). Methods of soil analysis. Part 4: Physical methods. Soil Sci. Soc. Am. Book series No 5 ASA and SSSA, Madison WI pp $201-228$

8. Juo A. S.R. (1979). Selected methods for soil and plant analysis. Int. Institute of Tropical Agriculture, Ibadan Nigeria. Manual series pp $35-36$

9. Klute A. (1986). Water retention, Laboratory methods. In Klute A (eds) methods of soil physical analysis part 1: physical and mineralogical methods $2^{\text {nd }}$ eds

10. Mbagwu J.S.C. (1992). Improving the productivity of a degraded ultisol in Nigeria using organic and inorganic amendments. Parts 2: changes in physical properties. Biores. Tech. 42: $167-175$

11. Mbah C. N. and Mbagwu J. S. C. (2003).Studies on decomposition mineralization rate and biochemical oxygen demand of organic wastes. Int. Journal of Agric. and Biological Science 2, 51 -54

12.

Mbah C.N., Itoro N (2012). Effects of poultry droppings and wood-ash on soil chemical properties and yield of maize on an Ultisol in Abakaliki, Southeast Nigeria.International Agriculture conference ANSUIA 2012, 6-9 ${ }^{\text {th }}$ May.Anambra State University ,Igbariam campus. Pp $416-420$

13. Mbah, C.N and Mbagwu J.S.C. (2006).Effect of animal wates on physiochemical properties of a Dysticleptosol and maize yield in South east Nigeria. Nigeria Journal of Soil Science. 16: 96 - 103

14. Mbah, C.N, Mbagwu J.S.C, Onyea V. N. and Anikwe, M.A.N.(2014). Effect of application of biofertilizer on soil densification, total porosity, aggregate stability, aggregate stability and maize yield in a Dystricleptosol at Abakaliki Nigeria. Journ.of Science and Tech. 10, $74-85$

15. Nnabude P. C and Mbagwu J.S.C. (1998). Soil water relations of Nigeria Typichaplustult amended with fresh and burnt rice-mill wastes. Soil and Tillage Res. 40:202 -214

16. Nottidge, D. O (2005). An investigation in the leguminous crop residue and wood ash for improving soil condition and productivity of maize (Zea Mays L) in south east Nigeria. Ph.D dissertation Michael Okpara University of Agriculture, Umudike.

17. Ohiri A.C. and Ano.D (1982).Characterization and evolution of some soils of rain forest zone of Nigeria. Proceedings of $17^{\text {th }}$ annual conf. of Soil Sci. Soc. Of Nigeria held at Nsukkapp $56-602$

18. Ojeniyi S.O and Adejobi, K.B (2002).Effect of wood-ash on nutrient composition, growth and yield of cereals and amaranthus. The Nigerian Agricultural Journal, 34: 46 -57

19. Oliver, M. A and Gregory, P. J. (2015).Soil, food security and human health.A review. European Journ. of Soil Sci, 66: $257-276$

20. Soil Survey Staff (2003) keys to soil taxonomy.Ninth edition.USAA / NRSC. Washington D.C. pp 332

21. Steel, G.D. and Torrie, J.H (1980).Procedure of statistics.A biometrical Approach. $2^{\text {nd }}$ edition New York McGrain Hill book (pp 633)

22. Tel D and Rao, F (1982). Automated and semi automated methods for soil and plant analysis. IITA manual series no 7 , $15-25$ 